\title{
The Image of New Woman as Portrayed in Jhumpa Lahiri's Novel The Lowland
}

\author{
D. Kavitha
}

Research Scholar

Department of English

Sri Padmavathi Mahila Viswavidyalayam

Tirupathi, Andhra Pradesh, India

ugc.kavitha@gmail.com

\author{
Prof. M. Neeraja \\ Department of English \\ Sri Padmavathi Mahila Viswavidyalayam \\ Tirupathi, Andhra Pradesh, India
}

\begin{abstract}
The last decade of the Victorian era witnessed a major shift in the social attitude of the woman. It was a break away from the patriarchal system, and women emerging as independent being and moving towards achieving gender equality. The 'New Woman' is considered as a precursor to the feminist movement and thus the legacy of New Woman lives on to this day. Jhumpa Lahiri, the significant writer of the Indian diaspora has emerged on the global literary scene with her remarkable writings. The novel has a compelling plot of family relations. It delineates the tender fraternal bond between Subhash and Udayan and how it gets affected by the various paths they chose in their lives. This intensely emotional tale unfolds diverse dimensions of the woman caught in the predicament of conservative cultural practices at home, political unrest in society and the life of an exile in the immigrant land. It also


explores Gauri's expression of identity, her struggle with love, Bela's choice for individuality and pragmatism in life has turned the novel into a unique narrative. In her second novel, 'The Lowland' Jhumpa portrays her women characters devaluing the patriarchal setup. They break the myths of womanhood and motherhood. Prominence is given to assert their position in society by restoring self-identity than nurturing deeper family relations. They fight with courage and confront various challenges in their marital relationship.

Keywords: Gender equality, New Woman, Diaspora and Self- identity

Introduction

The word 'New Woman' was coined by Sarah Grand in 1894. The term indicated intelligent, independent, educated and emancipated woman defying the stereotypical image of a woman. It was a voice raised against male supremacy and an attempt to re-demarcate gender roles. According to Dr.Andrzej Diniejko, the 'New Woman' was a cultural phenomenon striving for self-fulfilment and autonomy rather than sacrifice, prefers to be single than victimised by the conventional marriage set up.

Women writers have enriched the literature by painting the literary canvas with their narration, art of characterisation, themes, language and structure on par with their male counterparts. The second half of the $20^{\text {th }}$ century witnessed more number of women writers producing works that showcased the changing position of women in society.

The prominent women writers of Indian English Literature like Nayantara Sehgal, Kamala Markandeya, Anita Desai, Shashi Deshpande have established their identity in the literary arena. Many Indian immigrant women writers have also vitalized the Diaspora literature, to name some, Bharathi Mukherjee, Kiran Desai, Jhumpa Lahiri, Chitra Banerjee Divakaruni etc., These writers have dealt with the universal themes of immigration like an identity crisis, cultural conflict, nostalgia, assimilation, multiculturalism in their works. 
About the Author:

Jhumpa Lahiri is a second-generation Indian immigrant writer. She was born in 1967 to Bengali parents in Britain. She migrated to the U.S.A when she was three years old. She has a few short story collections and novels to her credit. Jhumpa was a recipient of the Pulitzer Prize for her debut work, 'Interpreter of Maladies'(1999). Her first novel 'The Namesake'(2003) is adopted into a film and her second novel,' The Lowland'(2013) was a finalist for both the Man Booker Prize and the National Book Award for Fiction. She has also authored 'Unaccustomed Earth' and 'In Other Words'.

The novel 'The Lowland' (2013) selected for the present study, is a heart-touching family drama in which interpersonal relationships between husband-wife, mother-daughter and parents-child are beautifully woven in the story. It has themes such as sacrifice, identity crisis, love marriage and parenthood etc.

The main purpose of this paper is to throw light on the transition of a traditional woman into a New Woman who was adapted into the western culture and ended up into rootlessness. It is an attempt to show how acculturation can affect immigrants' lives and alters their family structure and pushing them into disillusionment. The paper also brings forth the problems of displacement.

Jhumpa gives a realistic image of the 'New Woman' in her novel, 'The Lowland'. Only the two major woman characters in the novel, Gauri and Bela are considered for the present study. Jhumpa's women are very different from a traditional Indian woman. They prefer to be identified as individuals rather than women. They have a strong conviction for life and do not compromise in their attempt to retain their identity. They are confident, dynamic and capable of facing the challenges of life. 
In the present novel, women are portrayed as individuals breaking the rules of patriarchy and redefine their gender roles. Society ascribes the characteristics like love, sacrifice, obedience, loyalty to 'Ideal Woman' and characteristics like individuality, courage and independent nature to 'Man'. In fact, these characteristics are juxtaposed in the novel. Subhash, a major male character in the novel is a symbol of loyalty, sacrifice, liberal and the best version of motherhood, while the female protagonists are more assertive and authoritative and decisive. Both the female leads hardly strive to match the expectations of society of being dutiful wife, caring mother or loyal daughter but in turn, focus on establishing their own identity in the society.

Jhumpa's female characters in the novel, 'The Lowland' devalue the patriarchal setup. They break myths of womanhood and motherhood. They compromise family ties to assert their position in society, independence and self -identity. They fight with courage and resist various challenges in relationships including marital life.

\section{Gauri as New Woman}

Gauri is the most complex character in the novel. She was born in a large family with many sisters and a brother. All her sisters are much elder than her and were married after a few years she was born. Since her childhood, she had lived far from her parents for some reasons. She enjoyed the autonomy she was granted by them and glad that there was no authoritative control of her parents over her. She was sent to her maternal grand parents' house to live with her brother, Manash in Calcutta. The physical distance from her parents caused her having no deep emotional attachment with them. Gauri's grandfather, a retired Sanskrit professor and a voracious reader was always an inspiration to her in her life.

As a young woman, Gauri was discontented with her dark complexion and felt her facial features improper. To her, Udayan was the sole person who had caressed her and wholeheartedly accepted her along with her inadequate features. They married against the 
will of Udayan's parents. By marrying him, Gauri has entered a traditional Bengali threshold where her freedom and independence were curtailed due to her responsibility as a daughterin-law. She was always kept busy with household chores and continuing education looked impossible for her. The tradition imposes trials tribulations upon Gauri when she becomes a widow of Udayan. She was discriminated against in the guise of sacred ceremonies. Her inlaws start neglecting her and began to see her as a burden.

Gauri is liberated from the shackles of customs and traditions when she agreed to marry Subhash, brother of Udayan. She was taken to America along with him where she gives birth to Bela, daughter of Udayan. In America, She is constantly haunted by the memories of her first husband that often drifts her into loneliness. In order to escape from alienation, she throws herself into the assimilation of American culture. With her changed dressing and hairstyles, she tried to look an American. She is caught in the cultural conflict in her attempt to look at the western woman. However, her English accent, skin complexion and physical appearance revealed her Indian identity.

Gauri is annoyed with the monotony in her roles as a wife and mother. She doesn't want to step into those traditional roles again. Wanting to desperately come out of those roles, she begins to attend classes of Philosophy at the university. She tries to create a new identity for herself. Gauri feels betrayed when Subhash gives priority to look after Bela than allowing her to continue her studies fulltime, for he declines to have a baby sitter for Bela. This provokes her to resent Subhash and develop a grudge over him. It is to be noted the words of Betty Friedan here where she says that self-actualisation for women does not depend upon her husband or children. Further, she says,' to see a woman as a separate self, a human being who, in that respect, is no different in her need to grow than is a man'(264).

Gauri wanted to break free from all the bonds that she considers might hinder her establishing her identity. She abandons her six-year-old daughter and husband suddenly and 
leaves for California to work at the college that hired her. The new-found freedom allows her to have a life of her own choice in America. It is in her anguish to apprehend American life she distances herself from Indian culture where she even initiates a homosexual relationship with her scholar. The gender role of Gauri thus shifted 'from wife to widow, mother to a childless woman", (p291)

\section{Bela as New Woman}

Bela is another female lead character in the novel. The catastrophic decision of Gauri to abandon her family knocks the life of Bela into trauma. The terrible isolation from her mother marks a deep impression upon her for her whole life. Initially, Bela struggles to overcome the shock. She turns inward and introvert. Gradually she learns the lessons of isolation from her life. Her acceptance of truth transforms her and turns her to have a different perspective on life. She becomes highly individualistic to choose the career she prefers. Bela chooses to work as an environmentalist and also sometimes works as an agriculturist. She prefers to live as a nomad with no fixed address and insurance.

The emptiness in her life converts her defiant to tradition. The troubled marriage of her parents had a demonstrated impact on Bela which infused courage in her to denounce the system of marriage. She declares that she decides never to marry in life. She gives birth to an illicit child and decides to bring up the fatherless child. Thus Bela exhibits an indomitable spirit and faces the challenges of her life with confidence.

Conclusion

To sum up, the characters Gauri and Bela can be compared with New Woman of Victorian era, who no longer see marriage, followed by motherhood as inevitable in life. Gauri is married twice and becomes a mother but doesn't see fulfilment in her married life and motherhood. On the other hand, Bela discards the institution of marriage itself. Thus, Jhumpa Lahiri's women characters in the novel 'The Lowland' redefine the nature of woman 
and stand by their abilities breaking away from the stereotypes of womanhood. They face challenges of life with courage and with enormous inner strength

\section{References}

Lahiri, Jhumpa. The Lowland. U.K: Random House India, 2013

Friedan, Betty. The Feminine Mystique, Penguin Books Ltd, 1963

Dr.Diniejko, Andrzej, The New Woman Fiction

Mishra, Binod, Jhumpa Lahiri's The Lowland: A Narrative Pattern of a Broken Family,

IlluminatiJanuary 1, 2016, Illuminati, 58-66,6 